\title{
Tirilazad Prevention of Reperfusion Edema After Focal Ischemia in Cynomolgus Monkeys
}

\author{
Donald P. Boisvert and Edward D. Hall
}

\begin{abstract}
Background: The purpose of the present investigation was to determine if post-ischemic treatment with the 21 -aminosteroid lipid peroxidation inhibitor tirilazad mesylate (U-74006F) could affect reperfusion brain edema during the first $3 \mathrm{~h}$ following a $3 \mathrm{~h}$ period of middle cerebral artery occlusion-induced focal ischemia in cynomolgus monkeys. Methods: Adult female cynomolgus monkeys $(\mathrm{N}=14)$ were subjected under halothane anesthesia to a $3 \mathrm{~h}$ period of middle cerebral artery occlusion, followed by $3 \mathrm{~h}$ of reperfusion. U-74006F, 3.0 $\mathrm{mg} / \mathrm{kg}$ i.v. or citrate vehicle, was administered $10 \mathrm{~min}$ before beginning reperfusion. Multiple spin-echo ( 8 echoes: $\mathrm{TE}=26.3 \mathrm{msec} ; \mathrm{TR}=$ 3.0 secs; 2.35 Tesla) magnetic resonance imaging was performed every $30 \mathrm{~min}$, beginning at $\mathrm{lh}$ after reperfusion. Transverse relaxation rates (T2) for the caudate, putamen, cortex, insular cortex, parietal cortex and central white matter were calculated as an index of focal brain edema. After the final images, corresponding regions were removed for determination of water content by the wet weight/dry weight method. Results: The T2 measurements strongly suggested the presence of post-reperfusion edema in all gray matter, but not white matter, regions at $\mathrm{lh}$ after reperfusion in vehicle-treated animals. Significant attenuation of edema development was seen in the putamen and insular cortex in U-74006F-treated animals. An effect was also observed in the parietal cortex, but none in the caudate. The measurement of water content at $3 \mathrm{~h}$ after reperfusion yielded similar results. Conclusions: These results showing the ability of U-74006F to attenuate post-reperfusion brain edema support the concept that lipid peroxidation is a significant mediator of reperfusion brain edema after focal ischemia. The therapeutic window for U-74006F's anti-edema effect appears to be at least $3 \mathrm{~h}$ after the onset of focal ischemia since delaying treatment until just before reperfusion largely prevented subsequent edema in cortical regions and the putamen. The effects of U-74006F on edema may play a mechanistic role in the compound's reported neuroprotective efficacy in a variety of focal ischemia models.
\end{abstract}

RÉSUMÉ: Prévention de l'oedème de reperfusion au moyen du tirilazade après une ischémie focale chez le singe cynomolgus. Introduction: Le but de notre étude était de déterminer si le traitement post-ischémique au moyen d'un inhibiteur de la peroxydation lipidique, le mésylate de tirilazade (U-74006F) peut influencer l'oedème de reperfusion pendant les trois premières heures suivant une période de $3 \mathrm{~h}$ d'ischémie focale induite par occlusion de l'artère cérébrale moyenne chez des singes cynomolgus. Méthodes: Nous avons soumis des singes cynomolgus femelles, adultes, sous anesthésie à l'halothane, à une occlusion de l'artère cérébrale moyenne pendant une période de $3 \mathrm{~h}$, suivie d'une reperfusion de $3 \mathrm{~h}$. Le U-74006F, à la dose de $3.0 \mathrm{mg} / \mathrm{kg}$ i.v. ou du citrate (excipient), a été administré $10 \mathrm{~min}$ avant le début de la reperfusion. Nous les avons examinés par imagerie par résonance magnétique à spin-écho multiples ( 8 échos: $\mathrm{TE}=26.3 \mathrm{~ms}$; TR $=3.0 \mathrm{~s} ; 2.35$ Tesla) à toutes les $30 \mathrm{~min}, 1 \mathrm{~h}$ après la reperfusion. Les taux de relaxation transverse (T2) pour le noyau caudé, le putamen, le cortex, le cortex insulaire, le cortex pariétal et la substance blanche ont été calculés sous la forme d'un index de l'oedème cérébral focal. Suite aux images finales, les régions correspondantes étaient éliminées pour déterminer le contenu hydrique par la méthode du poids frais/poids sec. Résultats: Les mesures de T2 suggéraient fortement la présence d'oedème post-repertusion dans toute la substance grise, mais non dans la substance blanche, $1 \mathrm{~h}$ après la reperfusion chez les animaux ayant reçu l'excipient. La progression de l'oedème était significativement atténuée dans le putamen et le cortex insulaire chez les animaux traités au U-74006F. Un certain effet était également observé dans le cortex pariétal, mais non dans le noyau caudé. La mesure du contenu hydrique $3 \mathrm{~h}$ après la reperfusion a montré des résultats similaires. Conclusions: Ces résultats montrant la capacité de l'U-74006F d'atténuer l'oedème cérébral post-reperfusion supportent la notion que la peroxydation lipidique est un médiateur important de l'oedème cérébral de reperfusion après une ischémie focale. La fenêtre thérapeutique de l'effet anti-oedème de l'U-74006F semble être d'au moins $3 \mathrm{~h}$ après le début de l'ischémie focale, parce que le fait de commencer le traitement un peu avant le début de la reperfusion prévenait en grande partie l'oedème subséquent dans les régions corticales et le putamen. Les effets de l'U-74006F sur l'oedème peuvent jouer un rôle dans le mécanisme de neuroprotection qu'on attribue à cette substance dans plusieurs modèles d'ischémie focale.

Can. J. Neurol. Sci. 1996; 23: 46-52

Reperfusion of the brain following a period of focal ischemia of significant duration (1-3h) has been shown to result in rapidly developing brain edema that is associated with damage to the blood-brain barrier (BBB) and a resulting increase in microvascular permeability in rats ${ }^{1}$ and cats. ${ }^{2,3}$ The disruption of the BBB that occurs during the first few hours of reperfusion largely involves increased permeability to relatively small molecules (i.e., aminoisobutyric acid) and ions
$(\mathrm{Na}+, \mathrm{Cl}-)$ with water following into the brain parenchyma producing edema.' However, increased BBB permeability to

From the Division of Neurosurgery, University of Alberta, Faculty of Medicine, Edmonton (D.P.B.); Canadian Council on Animal Care, 315-350 Albert, Ottawa (D.P.B.); CNS Diseases Research, The Upjohn Company, Kalamazoo (E.D.H.) RECEIVED APRIL 19, 1995. ACCEPTED IN FINAL FORM AUGUST 22, 1995.

Reprint requests to: Dr. Edward D. Hall, CNS Diseases Research, The Upjohn Company Kalamazoo, Michigan 49001 USA 
larger molecules (proteins) is also seen during the first hours of reperfusion. ${ }^{2}$ While reperfusion appears to exacerbate BBB breakdown, ${ }^{\prime}$ an increase in brain capillary permeability is observable after as little as th of focal ischemia in the absence of reperfusion in rats. ${ }^{4}$ It has been suggested that the BBB damage that is triggered by ischemia and perhaps exacerbated by reperfusion may contribute significantly to the magnitude of neuronal damage and infarction in models of permanent and temporary focal ischemia. ${ }^{1.3}$ Therefore, efforts to limit ischemic BBB damage are likely to retard ischemic neuronal injury.

The mechanism of the early reperfusion-associated edema is believed to involve oxygen free radical-induced cerebral microvascular damage..$^{1,25-9}$ Specifically, it is likely that free radical-initiated ischemic brain damage is largely due to membrane lipid peroxidation. ${ }^{6-9}$ Thus, agents that limit free radical-induced lipid peroxidative damage to the cerebral microvasculature would be expected to counteract ischemic and post-ischemic BBB breakdown and cerebral edema. In that regard, the non-glucocorticoid 21 -aminosteroid tirilazad mesylate (U-74006F) is a potent inhibitor of oxygen radical-induced, iron-catalyzed lipid peroxidation that largely localizes in microvascular endothelium and has been shown to attenuate CNS injury in models of focal and global ischemia, subarachnoid hemorrhage and brain and spinal cord injury. ${ }^{10}$ In the present study, we examined the ability of a single i.v. dose of this compound, administered shortly before reperfusion, to limit the subsequent brain edema in cynomolgus monkeys subjected to a $3 \mathrm{~h}$ episode of middle cerebral artery (MCA) occlusion-induced focal ischemia. Quantitative serial magnetic resonance imaging (MRI; T2 spin echo) was employed to assess post-reperfusion edema progression in animals treated with $U$ $74006 \mathrm{~F}$ vs. its aqueous vehicle.

\section{Materials AND METhodS}

\section{Animals and Surgical Procedures}

The use of animals in these experiments was approved by the University of Alberta Health Sciences Animal Care Committee. Animal care was in compliance with the guidelines published by the Canadian Council on Animal Care (Guide to the Care and Use of Experimental Animals, Vol. 1, 2nd Ed., 1993; Canadian Council on Animal Care; Ottawa, Ontario, Canada).

Fourteen adult female cynomolgus monkeys, weighing 2.4 to $4.0 \mathrm{~kg}$, were employed in this study. Anesthesia was induced with ketamine hydrochloride (10-15 mg/ $\mathrm{kg}$ i.m.) followed by halothane (2-3\%) during surgery. Anesthesia maintenance during the experiment was accomplished with a halothane $(0.5-$ $1.5 \%$ ) and nitrous oxide/oxygen mixture. During anesthesia, paralysis was maintained with gallamine triethiodide $(2 \mathrm{mg} / \mathrm{kg}$ i.m. every $45 \mathrm{~min}$.). Body temperature (rectal) was maintained near $37^{\circ} \mathrm{C}$ by heating pad. A femoral artery was cannulated for blood pressure and blood gas/pH monitoring.

\section{Experimental}

All experiments were carried out in a blinded, placebocontrolled, randomized fashion. Each animal was subjected to right MCA occlusion, via a transorbital craniectomy, for a period of $3 \mathrm{~h}$ using a non-ferromagnetic aneurysm clip. Equal numbers were assigned to two groups: I) U-74006F, $3 \mathrm{mg} / \mathrm{kg}$ i.v. (1.5 $\mathrm{mg} / \mathrm{ml} ; 2 \mathrm{ml} / \mathrm{kg})$ or vehicle $(0.02 \mathrm{M}$ citric acid, monohydrate;
0.0032 sodium citrate, dihydrate; $0.08 \mathrm{M}$ sodium chloride; 2 $\mathrm{mg} / \mathrm{kg}) 10 \mathrm{~min}$. before reperfusion.

Multiple spin-echo $(8$ echoes: $\mathrm{TE}=26.3 \mathrm{msec}$; $\mathrm{TR}=3.0$ sec.; 2.35 Tesla) images were obtained at $30 \mathrm{~min}$. intervals between 1 and $3 \mathrm{~h}$ after reperfusion. Coronal images allowed bilateral measurement of transverse proton relaxation times (T2) in parietal and insular cortex, putamen, white matter and head of the caudate. T2 measurements were made from $15-25$ pixel regions (pixel size $=0.75 \times 0.75 \mathrm{~mm}$; slice thickness $=3.0 \mathrm{~mm}$ ). At $3 \mathrm{~h}$ of reperfusion, after the final MR image, the animals were killed by sodium pentobarbital injection and tissue samples obtained from the regions of interest for water content analysis (wet weight/dry weight method).

\section{Statistical Analysis}

One animal from each of the two groups had to be excluded due to technical MRI failures leaving $N=6$ for the vehicle and $\mathrm{U}-74006 \mathrm{~F}$ treated groups. The T2 and water content data was analyzed by one way ANOVA followed by Scheffe's test which allows for multiple comparison of the means. All data are expressed as mean \pm standard error.

\section{Results}

\section{Physiological Parameters}

Table I shows the physiological parameters for the vehicle and U-74006F treated groups on animals during magnetic resonance imaging. Both groups were equivalent in regards to body temperature, arterial blood gases and $\mathrm{pH}$ and mean arterial pressure.

\section{MR Imaging of Edema (T2 Values)}

Figure 1 displays the pseudo-color MRI images of two vehicle treated monkeys at $\mathrm{I}$ and $3 \mathrm{~h}$ of reperfusion. The reddish areas indicate increased brain edema compared to the non-edematous greenish background. Comparing the 1 and $3 \mathrm{~h}$ images shows the progressive nature of post-reperfusion edema. The numbers indicate the areas of edema quantitation: 1) parietal cortex, 2) insular cortex, 3) putamen, 4) white matter and 5) caudate. Edema was present in all areas except the white matter. Figure 2 shows MRI images from two U-74006F treated monkeys at $\mathrm{I}$ and $3 \mathrm{~h}$ of reperfusion which manifest much less evidence of edema than the vehicle treated monkey brains in Figure 1 with the exception of the caudate. It should be pointed out that because of differences in magnet tuning and shimming, image intensity is not strictly comparable between animals, but does accurately reflect changes in the same animal over the $3 \mathrm{~h}$ reperfusion period.

Table 1: Physiological parameters in adult female cynomolgus monkeys subjected to $3 \mathrm{~h}$ MCA occlusion plus $3 \mathrm{~h}$ of reperfusion and treated with either tirilazad mesylate (U-74006F) or its aqueous vehicle.

\begin{tabular}{|c|c|c|}
\hline & Vehicle & U-74006F \\
\hline Rectal temperature $\left({ }^{\circ} \mathrm{C}\right)$ & $37.2 \pm 0.1$ & $36.8 \pm 0.2$ \\
\hline $\mathrm{pCO}_{2}(\mathrm{~mm} \mathrm{Hg})$ & $37.9 \pm 1.2$ & $35.9 \pm 1.7$ \\
\hline $\mathrm{pO}_{2}(\mathrm{~mm} \mathrm{Hg})$ & $181.0 \pm 5.0$ & $190.0 \pm 13.0$ \\
\hline $\mathrm{pH}$ & $7.46 \pm 0.01$ & $7.46 \pm 0.02$ \\
\hline $\mathrm{MAP}(\mathrm{mm} \mathrm{Hg})$ & $82 \pm 3$ & $81 \pm 4$ \\
\hline
\end{tabular}

Values $=$ means \pm standard error for 6 animals/group. Measurements were made during $M R$ imaging. 


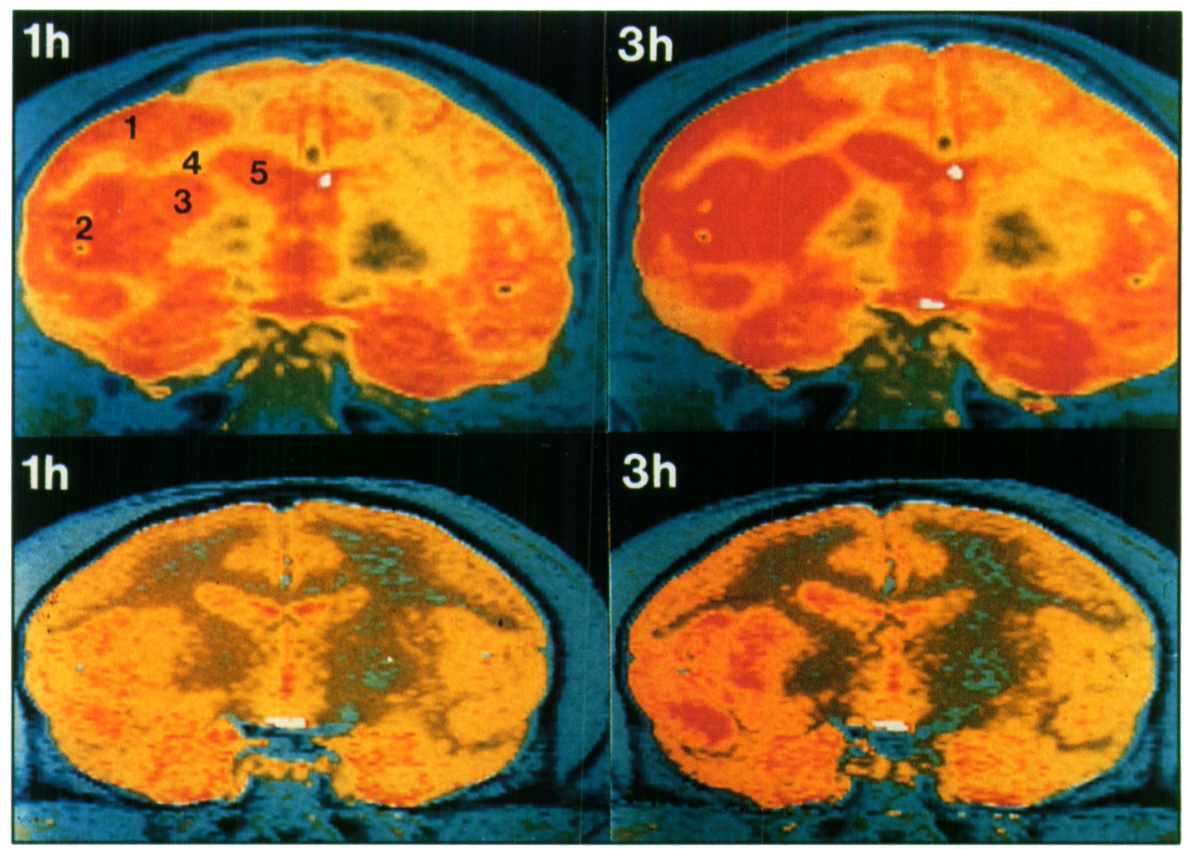

Figure I: MRI images of two vehicle-treated monkeys at Ih and 3 h of reperfusion following 3 h of right middle cerebral artery occlusion. The regions of interest are: 1) parietal cortex, 2) insular cortex, 3) putamen, 4) white matter and 5) caudate. Increased T2 intensity (red areas), most likely reflective of edema, is present in the right MCA distribution (viewer's left) at $\mathrm{l} h$ and increases between $\mathrm{h}$ h and $3 \mathrm{~h}$ of reperfusion.

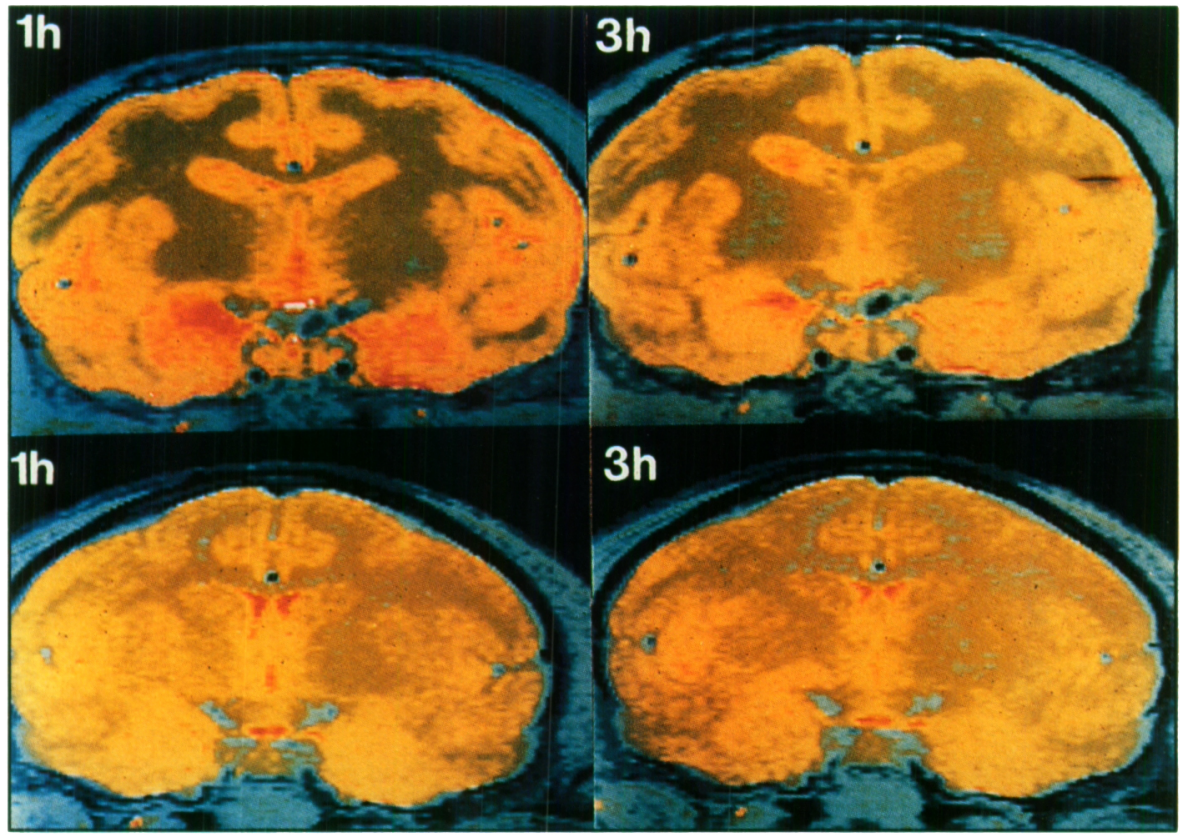

Figure 2: MRI images of two tirilazad-treated monkeys at $\mathrm{lh}$ and 3 h of reperfusion. Increased $T 2$ intensity (reperfusion edema) in the right (ischemic) hemisphere (viewer's left) is minimal to absent at $l h$ and $3 h$.

Figures $3 \mathrm{~A}-\mathrm{E}$ provide the quantitated time courses of the increase in $\mathrm{T} 2$ values in the 5 regions of interest indicative of post-reperfusion edema. Figure $3 \mathrm{~A}$ shows that edema was apparent in the caudate nucleus on the side of the MCA occlusion (right) in comparison to the contralateral side as early as lh after reperfusion. The mean $\mathrm{T} 2$ value remained higher than that in the contralateral non-ischemic side of the brain for the subsequent $2 \mathrm{~h}$. The time course of the changing T2 values was essentially the same in vehicle and U-74006F-treated animals. However, this increase in caudate $\mathrm{T} 2$ values was never actually statistically significant in comparison to the paired contralateral non-ischemic caudate for either group.

Figure 3B shows that in the case of the putamen, a progressive increase in $\mathrm{T} 2$ values in the vehicle-treated monkeys was more dramatic than in the caudate (Figure 3A) and did reach statistical significance ( $\mathrm{p}<0.05$ vs. contralateral putamen) by 


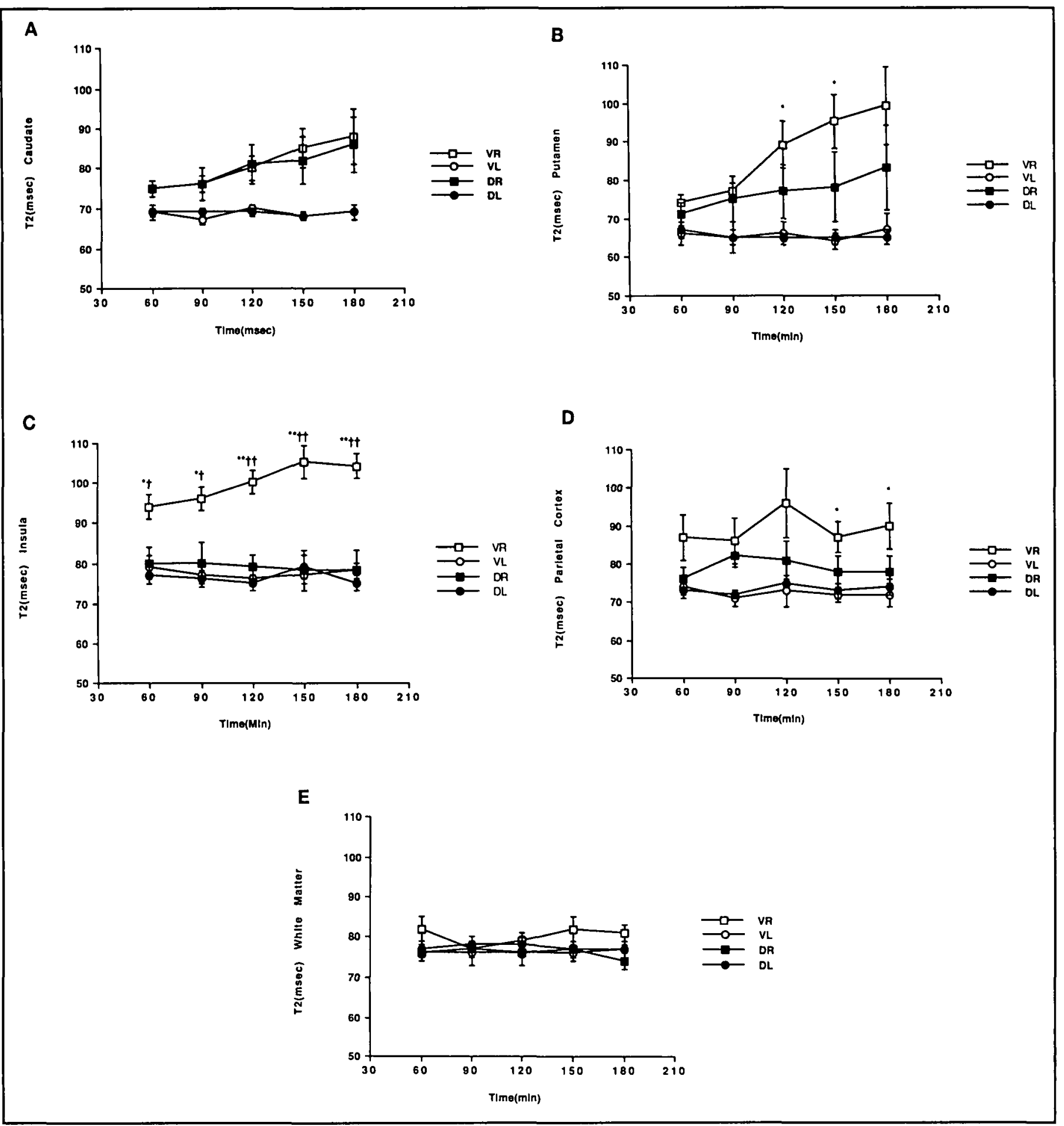

Figure 3: Mean \pm standard error MRI T2 values between th and 3 h of reperfusion following a 3 heriod of right MCA occlusion in: A) Parietal cortex, B) Insular cortex, C) Putamen, D) Caudate and E) White Matter. VR: vehicle right; VL: vehicle left; DR: Drug (tirilazad) right; DL: Drug (tirilazad) left. Comparison between hemispheres: $* p<0.05 ; * * p<0.01$ vs. vehicle left. Comparison of right hemisphere between vehicle and drug-treated groups: $t p<0.05 ;$ tt $p<0.01$.

$2 \mathrm{~h}$ after reperfusion. In contrast, the increase in the mean $\mathrm{T} 2$ parameter in the $\mathrm{U}-74006 \mathrm{~F}$-treated group never reached significance over the $3 \mathrm{~h}$ post-reperfusion time course.

In the case of the insular cortex (Figure $3 \mathrm{C}$ ), the increase in edema in the vehicle treated animals was the most pronounced of the regions examined. As early as $60 \mathrm{~min}$. after reperfusion, the $\mathrm{T} 2$ value in the ischemic parietal cortex was significantly higher than in the contralateral hemisphere, increasing further until $2.5 \mathrm{~h}$ at which time the rising T2 value plateaued. However, U-74006F completely prevented edema formation as the $\mathrm{T} 2$ time course 


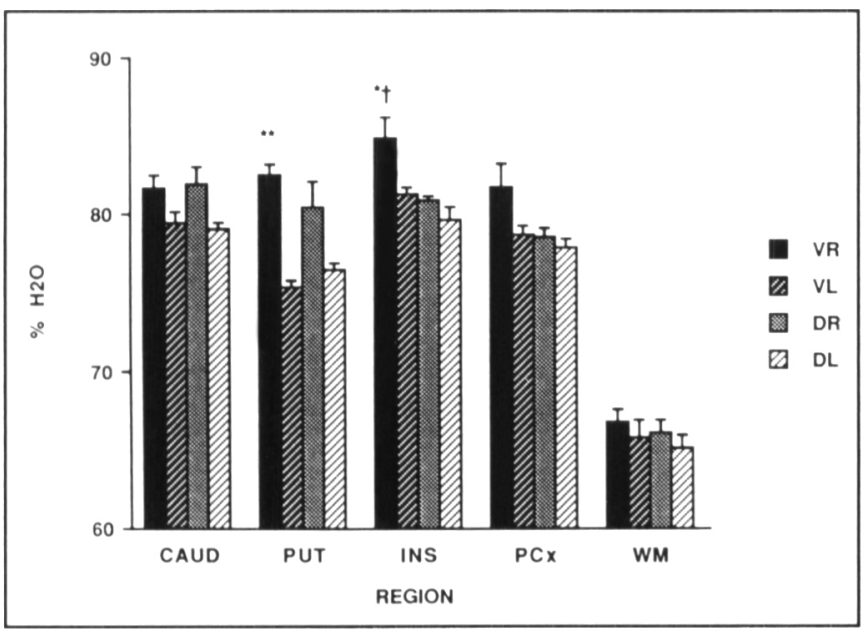

Figure 4: Mean \pm standard error water content values at 3 h of reperfusion. $C A U D=$ caudate, $P U T=$ putamen, $I N S=$ insular cortex,$P C x=$ parietal cortex and $W M=$ white matter. $V R$ : vehicle right: $V L$ : vehicle left: DR: Drug (tirilazad) right; DL: Drug (tirilazad) left. Comparison between hemispheres: $* p<0.05 ; * * p<0.01$ vs. vehicle left. Comparison of right hemisphere between vehicle and drug-treated groups: $t p<0.05$.

was superimposable upon those of the contralateral insular cortices from either group of monkeys. U-74006F dosing also resulted in a some apparent blunting of parietal cortical edema (Figure 3D) since at no reperfusion time was there a significant difference in the T2 values between the U-74006F treated ischemic (right) and non-ischemic (left) hemispheres. On the other hand, the T2 values in the vehicle-treated animals were significantly higher in the ischemic hemisphere compared to the non-ischemic hemisphere at 2.5 and $3 \mathrm{~h}$ after reperfusion.

No edema (i.e., increased T2) was observed in subcortical white matter over the course of $3 \mathrm{~h}$ of reperfusion.

\section{Water Content}

Figure 4 provides the actual water content of the ischemic and non-ischemic hemispheres from the vehicle and U-74006F treated monkeys after $3 \mathrm{~h}$ reperfusion. These data show excellent agreement with the MRI measurements. Again, the most pronounced attenuation of post-reperfusion edema by U-74006F was observed in the cortical regions (parietal and insular), an intermediate effect in the putamen and no effect in the caudate.

\section{Discussion}

The present results demonstrate the ability of a single 3 $\mathrm{mg} / \mathrm{kg}$ i.v. dose of the 21-aminosteroid tirilazad mesylate (U$74006 \mathrm{~F}$ ) to attenuate post-reperfusion cerebral edema during the first $3 \mathrm{~h}$ after the termination of a $3 \mathrm{~h}$ period of focal ischemia in cynomolgus monkeys. The therapeutic window for this effect is at least $3 \mathrm{~h}$ since the dose of $\mathrm{U}-74006 \mathrm{~F}$ was not administered until $10 \mathrm{~min}$ prior to reperfusion following a $3 \mathrm{~h}$ episode of MCA occlusion. Despite the delay in administration, U-74006F completely prevented edema in the insular cortex and nearly so in the parietal region. Some effect was also observed in the putamen while no reduction in edema was observed in the caudate nucleus. While the present experiments are confined to the first $3 \mathrm{~h}$ of reperfusion, the documented reduction in edema over that time course probably represents an effect, that with repeated U$74006 \mathrm{~F}$ dosing, would probably be persistent. Indeed, other experiments in rat permanent MCA occlusion models have shown that repeated post-ischemic administration of $\mathrm{U}-74006 \mathrm{~F}$ attenuates brain edema for as long as $24 \mathrm{~h} .^{11-13}$

Oxygen radicals have been strongly implicated in postischemic edema operating via a lipid peroxidative mechanism. ${ }^{2.5 .7-9}$ During the early phase of reperfusion, increased BBB permeability to ions, other small molecules, proteins and water has been demonstrated as the principal cause. It is increasingly clear that vascular endothelial cells are important sites of free radical formation and targets for peroxidative damage. ${ }^{5}$ Consistent with the role of lipid peroxidation in post-ischemic BBB damage is the observation that dosing with the lipid peroxidation inhibitor $\mathrm{U}-74006 \mathrm{~F}$, which is largely localized in cerebral vascular endothelium, ${ }^{10}$ acts to attenuate post-ischemic edema. The present study in a primate model of temporary focal ischemia extends the results of multiple previous studies in rat models of permanent MCA occlusion that have documented an effect of the compound to reduce brain parenchymal sodium and/or water accumulation during the first $24-72$ hours after the onset of ischemia. ${ }^{11-13}$ Moreover, U-74006F has been found to reduce BBB damage produced by exposure to arachidonic acid, ${ }^{14.15}$ iron, ${ }^{15}$ subarachnoid hemorrhage $^{15}$ and experimental head injury. ${ }^{16,17}$ Therefore, BBB protection and the associated reduction of cerebral edema are consistent actions of $\mathrm{U}-74006 \mathrm{~F}$ related to protection of endothelial functional and structural integrity. Similarly, U-74006F has been reported to protect endothelial-dependent relaxation in isolated aortic rings from oxygen radical-induced inactivation ${ }^{18}$ and to preserve hepatic endothelial structural integrity in a rat model of hemorrhagic shock. ${ }^{19}$

The molecular mechanism of the endothelial protection by $\mathrm{U}$ $74006 \mathrm{~F}$ is most likely inhibition of lipid peroxidation since this agent has been demonstrated to attenuate post-ischemic lipid peroxidation in models of focal ischemia coincident with histological neuroprotection. ${ }^{21,22}$ The lipid antioxidant action is based upon a chemical scavenging of membrane lipid radicals and a decrease in membrane fluidity which together inhibit the propagation of peroxidative reactions. ${ }^{10}$ Such reactions, if unchecked, could increase endothelial permeability. An additional anti-edema mechanism that stems from the inhibition of lipid peroxidation relates to the demonstrated $\mathrm{U}-74006 \mathrm{~F}$ reduction in post-insult elevation of brain leukotriene generation in models of focal and global cerebral ischemia ${ }^{23}$ and subarachnoid hemorrhage. ${ }^{24}$ Leukotrienes have been shown to increase BBB permeability. ${ }^{25}$ Thus, part of the antiedema action could be due to blunted post-ischemic leukotriene levels. However, this may be the result of decreased lipid peroxidation, because the leukotriene-forming 5-lipoxygenase is activated by lipid peroxides. ${ }^{26}$ In other words, attenuation of lipid peroxidation serves to limit 5-lipoxygenase activation.

It has been proposed that post-ischemic microvascular damage and the consequent increase in BBB permeability may be critical mechanisms of secondary brain parenchymal injury. ${ }^{7}$ Thus, the attenuation of this phenomenon may constitute a neuroprotective mechanism. In this regard, $\mathrm{U}-74006 \mathrm{~F}$ has been repeatedly shown to reduce neuronal necrosis or infarct size in focal ischemia models in gerbils, ${ }^{20}$ rats, ${ }^{22.27-29}$ cats, ${ }^{30}$ rabbits ${ }^{31}$ and baboons. ${ }^{32}$ While there have also been reports of failures of $\mathrm{U}-74006 \mathrm{~F}$ to reduce infarct size in some models in rats ${ }^{27}$ and cats, ${ }^{33-35}$ each of these negative studies employed a fixed dose 
level that may not have been optimal. Perhaps most relevant to the present study, are recent experiments in a baboon $3 \mathrm{~h} \mathrm{MCA}$ occlusion paradigm in which initial administration of $\mathrm{U}-74006 \mathrm{~F}$ in a $3 \mathrm{mg} / \mathrm{kg}$ i.v. bolus at $15 \mathrm{~min}$. prior to reperfusion (plus additional doses over a $24 \mathrm{~h}$ period) reduced 2 week infarct size by $40 \% .^{32}$ That study also involved primates subjected to an identical period of MCA occlusion and the same initial treatment dose of U-74006F as in the presently reported experiments. Thus, it is reasonable to speculate that the demonstrated reduction in early reperfusion edema probably relates mechanistically to later neuroprotection.

In summary, the results show that the 21-aminosteroid lipid peroxidation inhibitor tirilazad mesylate (U-74006F), which largely localizes in brain endothelial cells, ${ }^{10}$ effectively attenuates early post-reperfusion brain edema in a primate model of focal cerebral ischemia. This finding supports the concept that microvascular endothelial lipid peroxidation is a significant mediator of reperfusion-associated brain edema after focal ischemia. Although the present experiments did not encompass an assessment of actual neuroprotection, the reduction in edema may contribute to the reported ability of tirilazad to reduce ischemic neuronal damage and/or infarct size in models of focal ischemia, with or without reperfusion. The therapeutic window for the use of U-74006F appears to be at least $3 \mathrm{~h}$ after the onset of focal ischemia because delaying treatment until just before reperfusion nearly completely prevented subsequent edema for a full $3 \mathrm{~h}$ after reperfusion, at least in cerebral cortex. Thus, this compound shows potential for the treatment of ischemic stroke either alone or perhaps in conjunction with therapeutic maneuvers (i.e., thrombolytics) that facilitate reperfusion.

\section{ACKNOWLEDGEMENT} Canada.

This study was supported by a grant from The Upjohn Company of

\section{REFERENCES}

1. Yang G-Y, Betz AL. Reperfusion-induced injury to the blood-brain barrier after middle cerebral artery occlusion in rats. Stroke 1994; 25: 1658-1665.

2. Nelson CW, Wei EP, Povlishock JT, Kontos HA, Moskowitz MA. Oxygen radicals in cerebral ischemia. Am J Physiol 1992; 263: HI356-HI362.

3. Wilson DF, Shintaro G, Pastuszko A, Greenberg JH. Microvascular damage in the cortex of cat brain from middle cerebral artery occlusion and reperfusion. J Appl Physiol 1993; 74: 580-589.

4. Anwar M, Costa O, Sinha AK, Weiss HR. Middle cerebral artery occlusion increases cerebral capillary permeability. Neurol Res 1993; 15: 232-236.

5. Betz AL. Oxygen free radicals and the brain microvasculature. In: Pardridge W, ed. The Blood-Brain Barrier. New York: Raven Press, 1993; 303-321.

6. Braughler JM, Hall ED. Central nervous system trauma and stroke: I. Biochemical considerations for oxygen radical formation and lipid peroxidation. Free Rad Biol Med 1989; 6: 289-301.

7. Hall ED, Braughler JM. Central nervous system trauma and stroke: II. Physiological and pharmacological evidence for the involvement of oxygen radicals and lipid peroxidation. Free Rad Biol Med 1989; 6: 303-313

8. Siesjo BK, Agardh C-D, Bengtsson F. Free radicals and brain damage. Cerebrovasc Brain Metab Rev 1989; 1: 165-211.

9. Asano $\mathrm{T}$, Koide $\mathrm{T}$, Gotoh $\mathrm{O}$, et al. The role of free radicals and eicosanoids in the pathogenetic mechanism underlying ischemic brain edema. Mol Chem Neuropathol 1989; 10; 101-133.
10. Hall ED, McCall JM, Means ED. Therapeutic potential of the lazaroids (21-aminosteroids) in CNS trauma, ischemia and subarachnoid hemorrhage. Adv Pharmacol 1994; 28: 221-268.

11. Young W, Wojak JC, DeCrescito V. 21-Aminosteroid reduces ion shifts and edema in the rat middle cerebral artery occlusion model of regional ischemia. Stroke 1988; 19: 1013-1019.

12. Lythgoe DJ, Little RA, O'Shaughnessy CT, Steward MC. Effect of $\mathrm{U}-74006 \mathrm{~F}$ on oedema and infarct volumes following permanent occlusion of the middle cerebral artery in the rat. $\mathrm{Br} \mathrm{J}$ Pharmacol 1990; 100: 454P.

13. Karki A, Westergren I, Widner H, Johansson B. Tirilazad reduces brain edema after middle cerebral artery ligation in hypertensive rats. Acta Neurochir 1994; 60 (Suppl.): 310-313.

14. Hall ED, Travis MA. Inhibition of arachidonic acid-induced vasogenic brain edema by the non-glucocorticoid 21 -aminosteroid $U$ 74006F. Brain Res 1988; 451: 350-352.

15. Zuccarello M, Anderson DK. Protective effect of a 21 -aminosteroid on the blood-brain barrier following subarachnoid hemorrhage in rats. Stroke 1989; 20: 367-371.

16. Hall ED, Yonkers PA, Andrus PK, Cox JW, Anderson DK. Biochemistry and pharmacology of lipid antioxidants in acute brain and spinal cord injury. J Neurotrauma 1992; 9 (Suppl. 2): S425-S442.

17. Smith SL, Andrus PK, Zhang JR, Hall ED. Direct measurement of hydroxyl radical levels, lipid peroxidation and blood-brain barrier disruption following unilateral head injury in the rat. J Neurotrauma 1994; 11:393-404.

18. Mathews WR, Marshcke CK, McKenna R. Tirilazad mesylate protects endothelium from damage by reactive oxygen. J Mol Cell Cardiol 1992; 24 (Suppl. III): 517.

19. Eversole RR, Smith SL, Beuving LJ, Hall ED. Protective effect of the 21 -aminosteroid lipid peroxidation inhibitor tirilazad mesylate $(\mathrm{U}-74006 \mathrm{~F})$ on hepatic endothelium in experimental hemorrhagic shock. Circ Shock 1993; 40: 125-131.

20. Hall ED, Pazara KE, Braughler JM. 21-Aminosteroid lipid peroxidation inhibitor $\mathrm{U}-74006 \mathrm{~F}$ protects against cerebral ischemia in gerbils. Stroke 1988; 19: 997-1002.

21. Hall ED, Pazara KE, Braughler JM. Effects of tirilazad mesylate on post-ischemic brain lipid peroxidation and recovery of extracellular calcium in gerbils. Stroke 1991; 22: 361-366.

22. Umemura K, Wada K, Uematsu T, Mizuno A, Nakashima M. Effect of 2 l-aminosteroid lipid peroxidation inhibitor, U74006F, in the rat middle cerebral artery occlusion model. Eur J Pharmacol 1994; $25: 69-74$.

23. Andrus PK, Hall ED, Taylor BM, Sam LM, Sun FF. Effects of the lipid peroxidation inhibitor tirilazad mesylate (U-74006F) on gerbil brain eicosanoid levels in gerbil brain following ischemia and reperfusion. Brain Res 1994; 659: 126-132.

24. Gaetani P, Marzatico F, Lombardi D, Adinolfi D, Rodriguez y Baena R. Effects of high dose methylprednisolone and U$74006 \mathrm{~F}$ on eicosanoid synthesis after subarachnoid hemorrhage in rats. Stroke 1991; 22: 215-220.

25. Black KL, Hoff JT. Leukotrienes increase blood-brain barrier permeability following intraparenchymal injection in rats. Ann Neurol 1985; 18: 349-351.

26. Lands WEM. Interactions of lipid hydroperoxides with eicosanoid biosynthesis. Free Rad Biol Med 1985; 1: 97-101.

27. Xue D, Slivka A, Buchan AM. Tirilazad reduces cortical infarction after transient, but not permanent focal cerebral ischemia in rats. Stroke 1992; 23: 894-899.

28. Beck T, Bielenberg GW. The effects of two 21 -aminosteroids on overt infarct size 48 hours after middle cerebral artery occlusion in the rat. Brain Res 1991; 560: 159-162.

29. Park CK, Hall ED. Dose-response analysis of the 21-aminosteroid tirilazad mesylate (U-74006F) upon neurological outcome and ischemic brain damage in permanent focal cerebral ischemia. Brain Res 1994; 645: 157-163.

30. Silvia RC, Piercey MF, Hoffmann WE, et al. U-74006F, an inhibitor of lipid peroxidation, protects against lesion development following experimental stroke in the cat: histological and metabolic analysis. Soc Neurosci Abst 1987; 13: 1499. 
31. Wilson JT, Bednar MM, McAuliffe TL, Raymond S, Gross CE. The effect of the 21 -aminosteroid $\mathrm{U}-74006 \mathrm{~F}$ in a rabbit model of thromboembolic stroke. Neurosurgery 1992; 31: 929-934.

32. Mori E, Copeland BR, Thomas WS, Koziol JA, DelZoppo GT. Effect of tirilazad mesylate on middle cerebral artery occlusion/reperfusion in non-human primates. Cerebrovasc Dis 1995; 5: 342-349.

33. Gelb AW, Henderson SM, Zhang C. U-74,006F, a 21 -aminosteroid, does not ameliorate feline focal cerebral ischemia. J Neurosurg Anesthesiol 1990; 2: 240.
34. Myers RE, Kleinholz M, Wagner KR, de Courten-Myers GM. Effects of experimental aminosteroid on outcome of cerebrovascular occlusion in cats. Stroke 1990; 21: 179.

35. Takeshima R, Kirsch JR, Koehler RC, Traystman RJ. Tirilazad treatment does not decrease early brain injury after transient focal ischemia in cats. Stroke 1994; 25: 670-676. 